\title{
Antibacterial effects of cyanogenic glucoside isolated from the stem bark of Bauhinia rufescens Lam
}

\author{
H. USMAN ${ }^{1 *}$, F.I. ABDULRAHMAN ${ }^{1}$, I.A. AHMED ${ }^{1}$, A.H. KAITA ${ }^{2}$ and I.Z. KHAN ${ }^{1}$ \\ ${ }^{1}$ Department of Chemistry, University of Maiduguri, P.M.B. 1069, Maiduguri, Nigeria. \\ ${ }^{2}$ Department of Pharm. \& Medicinal Chemistry, Ahmadu Bello University, Zaria, Nigeria. \\ *Corresponding author; E-mail: husman321@yahoo.com; usmanhamidu@unimaid.edu.ng; \\ Mob. +2348028332246.
}

\begin{abstract}
The chemical contents and in vitro antibacterial effects of the n-butanol column fractions, stem bark methanol extracts of Bauhinia rufescens Lam. were evaluated in Gram-positive and Gram-negative bacteria using disc diffusion technique. The n-butanol soluble portion from the stem bark methanol extract was successively eluted to afford 10 pooled fractions by comparison of TLC chromatograms. The bioactive fraction (fraction D) was further chromatographed using the bioassay guided protocol to afford 4 sub-fractions from which a pure compound was isolated and characterized using spectral studies as: $(4 S, 6 R)-(Z)-6-(\beta-D-$ glucopyranosyloxy)-4-hydroxy-2-cyclohexenyl- $\Delta^{1, \alpha}$-acetonitrile-a cyclohexenyl cyano methylene known commonly as menisdaurin. Test bacteria were Bacillus subtilis, Corynaebacterium spp., Escherichia coli and Shigella dysenteriae. The diameters of inhibition zone on the Gram-positive bacteria was found in the range from11.83 \pm 0.17 (n-butanol Fraction D) to $17.33 \pm 0.67$ (Fraction D2-8); while on Gram-negative organism the values ranged from $11.50 \pm 0.29$ (n-butanol Fraction D) to $19.67 \pm 0.33$ (Fraction D2-8). The activity index (AI) showed that Fraction D2-8 (51.18\%) and Compound I [menisdaurin] (127.36\%) was highly sensitive to Corynaebacterium spp. and E. coli when computed with Erythromycin and Gentamicin respectively. Highest AI was exhibited by Fraction D2-8 (93.89\%) against S. dysenteriae when computed with ciprofloxacin. In continuation of our chemical studies and search for bioactive compounds from medicinal plants; this work, therefore, was aimed at characterizing and testing the antibacterial efficacy of the isolated compound in order to further confirm our earlier reports on use of this part of B. rufescens in some parts of Northern Nigeria as a treatment against diarrhoea and dysentery. This is the first report of the isolation and antibacterial activity of menisdaurin from $B$. rufescens.
\end{abstract}

(C) 2013 International Formulae Group. All rights reserved.

Keywords: Antibacterial, Bauhinia rufescens, cyanogenic glucoside, isolation, menisdaurin.

\section{INTRODUCTION}

Medicinal plants, being the reservoir for drug and lead compounds for many therapeutic agents, are relatively safer and more affordable than synthetic alternatives (Akah et al., 2007; Iwu et al., 1999). There is global resurgence in the use of herbal preparations especially in some developing countries like Nigeria. These preparations are gradually sandwich into the primary and secondary health care delivery systems (ElMahmood and Ameh, 2007). It has been estimated that more than $50 \%$ of Western drugs originated from plant materials 
(Robbers et al., 1996). Several plants are indicated in folk and other traditional systems of medicines as anti-infective agents (ElMahmood and Ameh, 2007). In recent times, there have been increases in antibiotic resistant strains of clinically important pathogens, which have led to the emergence of new bacterial strains that are multi-resistant (WHO, 2001, Aibinu et al., 2003; Aibinu et al., 2004; Odunayo et al., 2007). The nonavailability and high cost of new generation antibiotics with limited effective span have resulted in increase in morbidity and mortality among the populace (Williams, 2000). Therefore, it is pertinent to continue research on drugs from medicinal plant sources. Bauhinia rufescens Lam is a scandent shrub of the family Leguminosae sub-family Caesalpiniodeae (FAO-UNEP, 1983; Burkill, 1995); it is deciduous in the drier area and an evergreen in wetter areas. It has wide array of medicinal values; the stem bark is used as cure for diarrhoea, dysentery, leprosy and to reduce fever (Burkill, 1995). In continuation of our interest in chemical studies and search for bioactive compounds from medicinal plants and to further confirm our earlier work on the crude extracts and partitioned portions of the stem bark of B. rufescens (Usman et al., 2009a,b,c). This work, therefore, was aimed at isolating and characterizing bioactive compound using chromatographic/spectral studies and then testing its efficacy against test bacteria using the hole-in-plate disc diffusion technique.

\section{MATERIALS AND METHODS}

\section{Collection and identification of plant}

The plant material (voucher number \#003/2008; Bauhinia rufescens Lam) was collected from Gathla village (Long. $13^{\circ}$ $31.369^{\prime} \mathrm{E}$, Lat. $\left.11^{\circ} 00.562^{\prime} \mathrm{N}\right)$, Gwoza - Borno State, Nigeria in June, 2008. The herbarium specimen was identified by Prof. S.S Sanusi of Biological Science Department, and the voucher specimen was deposited at the Post graduate Research Laboratory, Department of Chemistry, University of Maiduguri, Nigeria for reference. The stem bark of the plant was air-dried under shade and pulverised into fine powder.

\section{Extraction of plant materials}

The concentrated n-butanol fractionated portion obtained from the crude methanol stem bark extract of $B$. rufescens (Usman et al., 2009a), was kept at $4{ }^{\circ} \mathrm{C}$ till use. The n-butanol Fraction D was subjected to detailed purification protocol using the column chromatography utilizing silica gel as adsorbent and in vitro antimicrobial susceptiblity analysis evaluated accordingly.

\section{Test bacteria}

Test bacteria were: Bacillus subtilis, Corynaebacterium spp. Escherichia coli and Shigella dysenteriae. The standard antibiotics disc used were Ciprofloxacin (5 $\mu \mathrm{g} / \mathrm{disc})$; Erythromycin $(5 \mu \mathrm{g} /$ disc $)$ and Gentamicin (10 $\mu \mathrm{g} / \mathrm{disc})$. These bacteria were clinical isolates obtained from the Department of Medical Microbiology and Department of Veterinary Medicine, University of Maiduguri, Maiduguri-Nigeria.

\section{Antimicrobial susceptibility test}

The n-butanol Fraction D portion and sub-fractions of the stem bark extract of $B$. rufescens was subjected to antimicrobial evaluation on two Gram-positive and two Gram-negative strains using the hole-in-plate disc diffusion technique as described by Forbes et al. (1990); Vlietinck et al. (1995); Usman et al. (2007). Our earlier report revealed that fraction $\mathrm{D}$ contains cardenolides, cardiac and cyanogenic glycosides, flavonoids, resins, tannins (Usman et al., 2012).

The n-butanol Fraction D portion and sub-fractions of the stem bark extract of $B$. rufescens was subjected to antimicrobial evaluation on two Gram positive and two Gram negative strains using the hole-in-plate disc diffusion technique as described by Forbes et al. (1990); Vlietinck et al. (1995); Usman et al. (2007). Our earlier report 
revealed that fraction $\mathrm{D}$ contains cardenolides, cardiac and cyanogenic glycosides, flavonoids, resins, tannins (Usman et al., 2012).

The extracts were made in three different stock concentrations of 1.5625 , 3.125 and $6.25 \mathrm{mg} / \mathrm{ml}$ by dissolving 0.015625 , 0.03125 and $0.0625 \mathrm{~g}$ respectively into $10 \mathrm{ml}$ each of $85 \%$ methanol in distilled water $(\mathrm{v} / \mathrm{v})$ - as vehicle. The bacteria were maintained on agar slants until use. The inocula were then prepared by subjecting the test bacteria in nutrient broth and incubated for 24 hours at 37 ${ }^{\circ} \mathrm{C}$. One millilitre of the diluted cultures was inoculated into $19 \mathrm{ml}$ sterile molten nutrient agar $\left(48{ }^{\circ} \mathrm{C}\right)$ and poured into sterile Petri dishes. Afterwards, holes of $9 \mathrm{~mm}$ internal diameter were bored onto the solidified and inoculated nutrient agar plates using sterilized number VI cork borer. All the holes were filled with equal volumes of $0.1 \mathrm{ml}$ of different concentration to afford 0.156 , $0.3125,0.625 \mathrm{mg} / \mathrm{hole}$. Standard discs were placed on bacterial-inoculated nutrient agar plate; the extracts were allowed to diffuse into the agar for an hour. Thereafter, the plates were incubated overnight at $37^{\circ} \mathrm{C}$. The extract was independently tested in triplicate. Diameters of inhibition zones (DIZ) $\geq 10 \mathrm{~mm}$ exhibited by plant extracts were considered active (Usman et al., 2007).

Activity index (AI)

This was evaluated as $100 \mathrm{x}$ diameters of inhibition zone of extract $\div$ diameters of inhibition zone of the standard antibiotic (expressed as \%) (Shahidi, 2004).

Percent actvitiy $(P A)$

This was calculated as $100 \mathrm{x}$ number of susceptible strains to a specific extract $\div$ total number of tested bacterial strains. This was expressed as \% Gram positive, \% Gram negative and $\% \mathrm{~T}$ as total activity against both Gram positive and Gram negative (Shahidi, 2004).

\section{Bacterial susceptibility index (BSI)}

This was calculated as $100 \mathrm{x}$ number of extracts effective against each bacterial strain $\div$ number of total samples (expressed as \%) (Shahidi, 2004).

Average percent of bacterial susceptibility (APBS)

This was determined as sum of $\%$ activities $(\% \mathrm{G}+, \% \mathrm{G}-$, or $\% \mathrm{~T}) \div$ number of total samples, this represents overall susceptibility of each group of bacterial strain (Shahidi, 2004).

\section{Spectral intensity index (SII)}

This was determined as: Mean diameters of inhibition zones ( $\mathrm{mm})$ of all sensitive bacterial strains to a specific sample x \% $\mathrm{T} \div 100$ (Shahidi, 2004).

\section{Statistical analysis}

The statistical analysis involved the determination of mean differences among the zone of inhibition exhibited by the extracts against each organism and the standard antibiotics analysed using One-way ANOVA with Student-Newman-Keuls Multiple comparisons test performed using GraphPad InStat (GraphPad Software, 1998).

\section{Chromatographic separation of the n- butanol portion \\ The crude methanol extract was} partitioned with various organic solvents as mentioned earlier (Usman et al., 2009b). The most susceptible portion (n-butanol fraction) was subjected to column chromatographic separation which afforded 10 pooled fractions coded A-J as reported earlier (Usman et al., 2012). Fraction D was observed to be active and then subjected to further purification protocol.

\section{Isolation of compound I}

About $15.0 \mathrm{~g}$ of Sephadex LH-20 (Amersham Biosciences, Sweden) were packed manually into a column of $45 \mathrm{~cm}$ x 1.4 $\mathrm{cm}$ i.d. The sephadex LH-20 was allowed to swell in $\mathrm{MeOH}$ overnight and cautiously filled into the column using a glass funnel. The gel was then allowed to settle and pack for $24 \mathrm{hrs}$. The air bubbles were avoided and care was taken not to dry the column. About $1.5 \mathrm{~g}$ of $\mathrm{n}$ butanol fraction $\mathrm{D}$ was mounted on the 
already equilibrated sephadex-fixed column. A total of 18 sub-fractions were generated and pooled in four relative groups: FD1, FD2-8, FD9-11 and FD12-18. FD1 (35 mg) and FD2$8 \quad(80 \mathrm{mg})$ showed potent antimicrobial activities and thus separated further for isolation of the active compound(s). Continuous re-purification of FD2-8 by repetitive sephadex column chromatography and PTLC revealed D2-8:1 (56 $\mathrm{mg})$ as pure colourless crystalline plates; the M.P. was found to be $170-172{ }^{\circ} \mathrm{C}$ uncorrected. The isolated compound coded 'Compound I' was characterized using various analytical techniques: \{IR, UV-Vis, NMR [ ${ }^{1} \mathrm{HMNR}$, COSY, ${ }^{13}$ CNMR, DEPT, NOESY, HMBC, HMQC] $\}$ and was soluble in methanol and ethanol, but insoluble in petroleum ether, benzene and chloroform.

\section{RESULTS}

\section{Characterization of compound I}

The structure of compound I was elucidated and characterized using various analytical techniques. The Infra-red (IR) spectrum reveal strong absorption band around $2200 \mathrm{~cm}^{-1}$. The UV absorption maximum at $259.0 \mathrm{~nm}$.

The HNMR spectrum showed diagnostic peak for glucose at $4.571 \mathrm{ppm}$, a series of doublet-like signals centered at 3.336, 3.394, 3.287, 3.663, $3.881 \mathrm{ppm}$ were equally found; two doublets appeared at 6.289 and $6.202 \mathrm{ppm}$ and also at $5.512 \mathrm{ppm}$. Other signals were found at 4.913, 4.371, 2.252 and $2.033 \mathrm{ppm}$. The COSY spectrum showed the $\mathrm{H}-\mathrm{H}$ couplings; the proton at $4.371 \mathrm{ppm}$ coupled to protons at 2.033 and $2.252 \mathrm{ppm}$ among others.

The ${ }^{13} \mathrm{CNMR}$ spectrum of the compound I in methanol exhibited fourteen carbon atoms approximately equal in height with some having characteristic chemical shifts equivalence. Definitive peaks were observed at $36.14,63.11,65.42,71.73,72.66$, $74.55,78.02,78.13,96.86$ ppm. Others downfield peaks were at 101.59, 118.20, $127.85,140.65$ and $157.26 \mathrm{ppm}$. The DEPT spectrum revealed that peaks at $157.26 \mathrm{ppm}$ and $118.20 \mathrm{ppm}$ lacks proton, those at 36.14 ppm and $63.11 \mathrm{ppm}$ were methylene groups while the other nine peaks bears one hydrogen each 71.73, 72.66, 74.55, 78.02, 78.13, 96.86, $101.59,127.85$ and $140.65 \mathrm{ppm}$.

The heteronuclear multiple bond quantum coherence (HMQC) spectra showed correlations between the proton at $5.512 \mathrm{ppm}$ and the carbon at $157.26 \mathrm{ppm}$. This carbon also resonates with the peak at $4.913 \mathrm{ppm}$. The heteronuclear multiple bond coherence (HMBC) spectrum revealed strong long range-correlations between proton at 5.491 ppm and carbon at $127.85 \mathrm{ppm}$, this proton equally interacted with the carbon at 118.20 ppm. Weak interactions were noted between proton at $5.491 \mathrm{ppm}$ with the carbon at 74.55 ppm as well as carbon at $157.26 \mathrm{ppm}$. The NOESY spectra showed that proton at 4.373 ppm interacted very well with proton at 6.202 ppm while the proton at $4.913 \mathrm{ppm}$ showed interaction with that $4.571 \mathrm{ppm}$. Others were observed between 4.571 and 2.252 ppm; 2.033 ppm.

Bacterial susceptibility pattern of subfractions $D$ and compound I

The results of the bacterial susceptibility pattern of the n-butanol column fraction $\mathrm{D}$ and its sub-fraction at the dose of $0.3125 \mathrm{mg} /$ hole are presented in Table 1 . The activities ranged from $11.83 \pm 0.17$ to $19.00 \pm$ 0.00 among the organisms tested. Table 2 shows the susceptibility pattern of D2-8 and compound I. Least activity of $13.33 \pm 0.33$ was exhibited by sub-fraction D2-8 at concentration of $0.156 \mathrm{mg} / \mathrm{hole}$ against $B$. subtilis while the highest activity was expressed by the same sub-fraction but at $0.625 \mathrm{mg} / \mathrm{hole}$ against $S$. dysenteriae. The sensitivity indices namely the activity index, bacterial susceptibility index, spectral intensity index and average percent of bacterial susceptibility were shown on Table $3 a, 3 b$. 


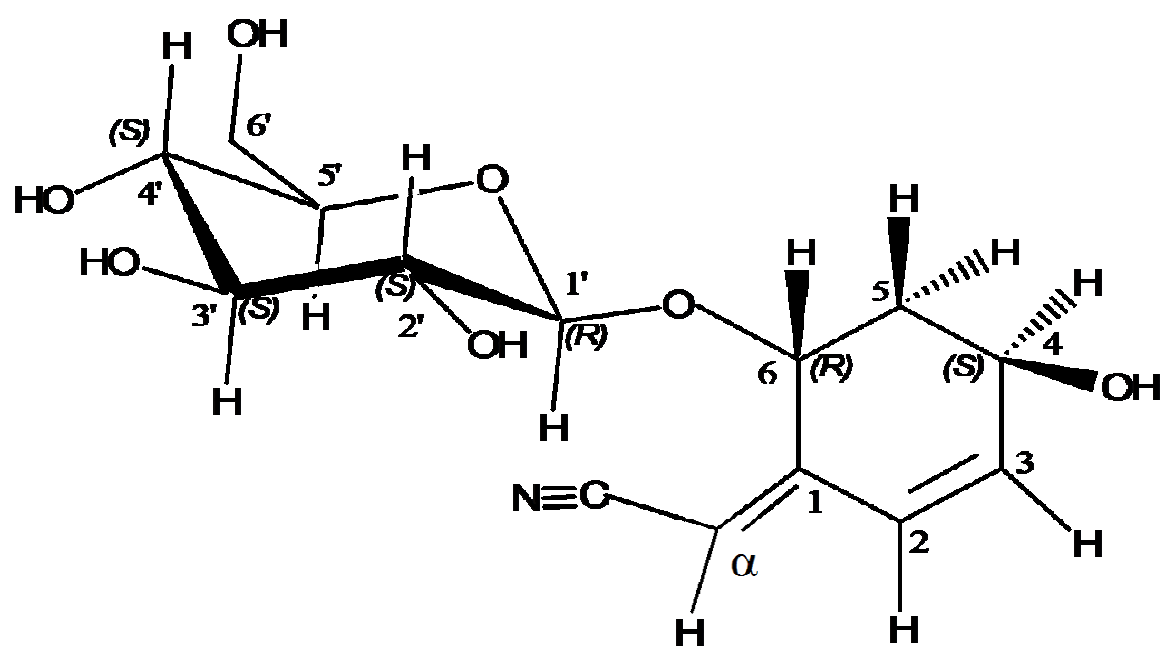

Figure 1: Compound I: (4S, 6R)-(Z)-6-( $\beta$-D-glucopyranosyloxy)-4-hydroxy-2-cyclohexenyl$\Delta^{1, \alpha}$-acetonitrile-a cyclohexenyl cyano methylene.

Table 1: Effects of column fraction D and sub-fractions of the n-butanol portion of the stem bark of B. rufescens on some bacteria at $0.3125 \mathrm{mg} / \mathrm{hole}$.

\begin{tabular}{|c|c|c|c|c|c|}
\hline \multirow{2}{*}{ S/No } & \multirow{2}{*}{ Fractions } & \multicolumn{4}{|c|}{ Bacteria/diameters of Inhibition zone (mm) } \\
\hline & & B. subtilis & Corynaeb. spp. & E. coli & S. dysenteriae \\
\hline 1 & NBD & $11.83 \pm 0.17^{\mathrm{a}}$ & $13.17 \pm 0.17^{\mathrm{a}}$ & $11.50 \pm 0.29^{\mathrm{a}}$ & $14.33 \pm 0.17^{\mathrm{a}}$ \\
\hline 2 & D1 & $16.33 \pm 0.33^{\mathrm{b}}$ & $16.67 \pm 0.17^{\mathrm{b}}$ & $15.33 \pm 0.33^{b, c}$ & $17.17 \pm 0.60^{\mathrm{b}}$ \\
\hline 3 & D2-8 & $16.67 \pm 0.33^{b}$ & $16.33 \pm 0.33^{b}$ & $16.33 \pm 0.33^{b}$ & $19.00 \pm 0.00^{b}$ \\
\hline 4 & D9-11 & $15.67 \pm 0.33^{b}$ & $14.33 \pm 0.33^{b}$ & $17.67 \pm 0.17^{\mathrm{d}}$ & $17.67 \pm 0.67^{b}$ \\
\hline 5 & D12-18 & $16.67 \pm 0.88^{b}$ & $15.33 \pm 0.33^{b}$ & $14.33 \pm 0.33^{\mathrm{b}}$ & $17.67 \pm 0.33^{b}$ \\
\hline 6 & $\begin{array}{l}\text { Ciprofloxacin } \\
(5 \mu \mathrm{g} / \text { disc })\end{array}$ & $25.33 \pm 0.33^{\mathrm{c}}$ & $36.00 \pm 1.00^{\mathrm{c}}$ & $26.67 \pm 0.67^{\mathrm{e}}$ & $20.00 \pm 0.00^{\mathrm{b}, \mathrm{c}}$ \\
\hline 7 & $\begin{array}{l}\text { Erythromycin } \\
(5 \mu \mathrm{g} / \text { disc })\end{array}$ & $23.67 \pm 0.67^{\mathrm{c}}$ & $33.00 \pm 0.00^{\mathrm{d}}$ & $28.33 \pm 0.33^{f}$ & $19.83 \pm 0.17^{b, c}$ \\
\hline 8 & $\begin{array}{l}\text { Gentamicin } \\
(10 \mu \mathrm{g} / \text { disc })\end{array}$ & $24.33 \pm 0.33^{\mathrm{c}}$ & $22.33 \pm 1.36^{\mathrm{e}}$ & $14.00 \pm 0.00^{\mathrm{b}}$ & $17.33 \pm 0.67^{b}$ \\
\hline
\end{tabular}


Table 2: Effects of compound I and column fraction D2-8 of the n-butanol portion of the stem bark of $B$. rufescens on some bacteria at various doses.

\begin{tabular}{|c|c|c|c|c|c|}
\hline \multirow[t]{2}{*}{ S/No } & \multirow[t]{2}{*}{ Dose (mg/hole) } & \multicolumn{4}{|c|}{ Bacteria/diameters of inhibition zone (mm) } \\
\hline & & B. subtilis & Corynaeb. spp. & E. coli & S. dysenteriae \\
\hline 1 & $\begin{array}{l}\text { D2-8 } \\
(0.625)\end{array}$ & $17.17 \pm 0.17^{\mathrm{a}, \mathrm{b}}$ & $16.67 \pm 0.33^{\mathrm{a}}$ & $18.33 \pm 0.33^{\mathrm{a}}$ & $19.67 \pm 0.33^{\mathrm{a}}$ \\
\hline 2 & $\begin{array}{l}\text { Compound I } \\
(0.625)\end{array}$ & $17.33 \pm 0.67^{b}$ & $15.33 \pm 0.33^{\mathrm{a}}$ & $17.33 \pm 0.33^{\mathrm{a}}$ & $17.33 \pm 0.33^{b}$ \\
\hline 3 & $\begin{array}{l}\text { D2-8 } \\
(0.313)\end{array}$ & $16.67 \pm 0.33^{b, c}$ & $16.33 \pm 0.33^{\mathrm{a}}$ & $16.33 \pm 0.33^{\mathrm{b}}$ & $19.00 \pm 0.00^{\mathrm{a}}$ \\
\hline 4 & $\begin{array}{l}\text { Compound I } \\
(0.313)\end{array}$ & $14.33 \pm 0.33^{\mathrm{c}}$ & $16.83 \pm 0.33^{\mathrm{a}}$ & $18.33 \pm 0.33^{\mathrm{a}}$ & $14.33 \pm 0.88^{\mathrm{d}}$ \\
\hline 5 & $\begin{array}{l}\text { D2-8 } \\
(0.156)\end{array}$ & $13.33 \pm 0.33^{\mathrm{c}}$ & $17.67 \pm 0.33^{\mathrm{a}}$ & $14.67 \pm 0.17^{\mathrm{c}}$ & $17.67 \pm 0.17^{\mathrm{c}}$ \\
\hline 6 & $\begin{array}{l}\text { Ciprofloxacin } \\
(5 \mu \mathrm{g} / \mathrm{disc})\end{array}$ & $25.33 \pm 0.33^{\mathrm{d}}$ & $36.00 \pm 1.00^{b}$ & $26.67 \pm 0.67^{d}$ & $20.00 \pm 0.00^{\mathrm{a}}$ \\
\hline 7 & $\begin{array}{l}\text { Erythromycin } \\
(5 \mu \mathrm{g} / \mathrm{disc})\end{array}$ & $23.67 \pm 0.67^{\mathrm{d}}$ & $33.00 \pm 0.00^{\mathrm{c}}$ & $28.33 \pm 0.33^{\mathrm{e}}$ & $19.83 \pm 0.17^{\mathrm{a}}$ \\
\hline 8 & $\begin{array}{l}\text { Gentamicin } \\
(10 \mu \mathrm{g} / \text { disc })\end{array}$ & $24.33 \pm 0.33^{\mathrm{d}}$ & $22.33 \pm 1.36^{\mathrm{d}}$ & $14.00 \pm 0.00^{\mathrm{c}}$ & $17.33 \pm 0.67^{\mathrm{c}}$ \\
\hline
\end{tabular}
Key: Means with different superscript along same column are significantly different $(\mathrm{P}<0.05)$. Data are presented as mean \pm SEM, $n=3$

Table 3a: Activity and bacterial susceptibility indices of compound I, fraction D and sub-fractions of the n-butanol portion of the stem bark of B. rufescens on some bacteria.

\begin{tabular}{|c|c|c|c|c|c|c|}
\hline \multirow{3}{*}{$\begin{array}{l}\text { Fractions } \\
\text { D }\end{array}$} & \multicolumn{6}{|c|}{ Activity index (\%) } \\
\hline & B. subtilis & Coryneab. spp. & \multicolumn{2}{|c|}{ E. coli } & \multicolumn{2}{|c|}{ S. dysenteriae } \\
\hline & ${ }^{\mathrm{a}} 60.76 \quad{ }^{\mathrm{b}} 65.02$ & $\mathrm{~b}_{45.12}$ & ${ }^{\mathrm{a}} 54.14$ & ${ }^{\mathrm{c}} 103.14$ & ${ }^{\mathrm{a}} 75.30$ & $\begin{array}{c}\mathrm{c} 86.90 \\
\end{array}$ \\
\hline D1 & ${ }^{\mathrm{a}} 64.47 \quad{ }^{\mathrm{b}} 68.99$ & ${ }^{\mathrm{b}} 50.52$ & ${ }^{\mathrm{a}} 57.48$ & ${ }^{\mathrm{c}} 109.50$ & ${ }^{\mathrm{a}} 85.85$ & ${ }^{\mathrm{c}} 99.08$ \\
\hline D2-8 & ${ }^{\mathrm{a}} 62.07 \quad{ }^{\mathrm{b}} 66.41$ & ${ }^{\mathrm{b}} 51.18$ & ${ }^{\mathrm{a}} 61.03$ & ${ }^{\mathrm{a}} 116.29$ & ${ }^{\mathrm{a}} 93.89$ & ${ }^{\mathrm{c}} 108.37$ \\
\hline D9-11 & ${ }^{\mathrm{a}} 61.86 \quad{ }^{\mathrm{b}} 66.20$ & $\mathrm{~b}_{43.42}$ & ${ }^{\mathrm{a}} 66.24$ & ${ }^{\mathrm{c}} 126.21$ & a 88.33 & ${ }^{c} 101.96$ \\
\hline D12-18 & ${ }^{\mathrm{a}} 65.81 \quad{ }^{\mathrm{b}} 70.43$ & ${ }^{\mathrm{a}} 42.58 \quad{ }^{\mathrm{b}} 46.45$ & a53.73 & ${ }^{\mathrm{c}} 102.36$ & a 88.35 & ${ }^{\mathrm{c}} 101.96$ \\
\hline Compound I & ${ }^{\mathrm{a}} 62.50 \quad{ }^{\mathrm{b}} 66.88$ & ${ }^{\mathrm{a}} 44.67 \quad \mathrm{~b} 48.73$ & ${ }^{\mathrm{a}} 66.89$ & ${ }^{\mathrm{c}} 127.36$ & ${ }^{\mathrm{a}} 79.15$ & $\begin{array}{c}{ }^{c} 91.34 \\
\end{array}$ \\
\hline *BSI (\%) & 79.17 & 87.50 & 79.17 & & 91.67 & \\
\hline
\end{tabular}


Table 3b: Percent activity and average percent of bacterial susceptibility of compound I, fraction D and sub-fractions of the n-butanol portion of the stem bark of B. rufescens on some bacteria.

\begin{tabular}{|c|c|c|c|c|c|c|c|}
\hline \multirow{3}{*}{ Fractions } & \multicolumn{3}{|c|}{ Percent Activity (\%) } & \multirow{3}{*}{$\begin{array}{c}* \text { Spectral Intensity } \\
\text { Index }\end{array}$} & \multirow{2}{*}{\multicolumn{3}{|c|}{$\begin{array}{c}\text { Average Percent of } \\
\text { Bacterial Susceptibility } \\
(\%)\end{array}$}} \\
\hline & \multirow[t]{2}{*}{ G+ve } & \multirow[t]{2}{*}{ G-ve } & \multirow[t]{2}{*}{$\% \mathrm{~T}$} & & & & \\
\hline & & & & & G+ve & G-ve & $\% \mathrm{~T}$ \\
\hline $\bar{D}$ & 96.30 & 92.60 & 94.45 & $14.24^{\mathrm{a}}$ & & & \\
\hline & & & & & 93.33 & 85.00 & 89.17 \\
\hline D1 & 100 & 100 & 100 & $14.60^{\mathrm{b}}$ & & & \\
\hline D2-8 & 83.33 & 83.33 & 83.33 & $15.09^{\mathrm{c}}$ & & & \\
\hline D9-11 & 100 & 100 & 100 & $14.57^{b}$ & & & \\
\hline D12-18 & 100 & 66.67 & 83.34 & $14.27^{\mathrm{a}}$ & & & \\
\hline Compound I & 83.33 & 75.00 & 79.17 & $14.62^{\mathrm{b}}$ & & & \\
\hline
\end{tabular}

Key: G+ve = Gram-positive; G-ve = Gram-negative; T= total, *values with different superscript along same column are statistically significant $(\mathrm{P}<0.05), * \geq 15 \mathrm{~mm}$ (DIZ) as the susceptible value.

\section{DISCUSSION}

The structure of compound I was elucidated and characterized using the analytical techniques. In structure elucidation of cyanogenic compounds, the Infra-red (IR) spectrum is a diagnostic tool that is expected to reveal strong nitrile absorption as a result of significant dipole moment associated with the $\mathrm{CN}$ bond leading to a significant change when it interacts with IR radiation usually appearing as an intense sharp peak at $2200-2280 \mathrm{~cm}^{-1}$. In fact, very few other groups absorb at this region with this intensity and also together with a $\mathrm{C}=\mathrm{C}$ stretching vibrations at $1620 \mathrm{~cm}^{-1}$ (Eudea et al., 1983). The nitrile group is a reliable functional group that is generally easy to identify. From the IR spectrum, the following wave numbers were observed and assigned accordingly: $3359 \mathrm{~cm}^{-1}\left(-\mathrm{OH}_{\text {(str. }-\mathrm{HB})}\right)$, $2954 \mathrm{~cm}^{-1}-\mathrm{CH}_{2}\left(\mathrm{v}_{\text {asy }}\right) ; 2845 \mathrm{~cm}^{-1}\left(-\mathrm{CH}_{2}\left(\mathrm{v}_{\mathrm{sym}}\right)\right.$; $2224 \mathrm{~cm}^{-1}(-\mathrm{CN}) ; 1637 \mathrm{~cm}^{-1}\left(-\mathrm{C}=\mathrm{C}\left(\mathrm{v}_{\text {str. }}\right) ; 1457\right.$ $\mathrm{cm}^{-1} \quad\left(-\mathrm{CH}_{\text {(bend[rocking]) }}\right) ; 1424 \mathrm{~cm}^{-1} \quad\left(-\mathrm{C}=\mathrm{C}_{\text {(bend }}\right.$ [scis]) $) ; 1018 \mathrm{~cm}^{-1}\left(-\mathrm{C}-\mathrm{O}_{(\text {str }}\right)$; (Takahashi et al., 1978; Seigler et al., 2005). Worthy of note is the broad band between 1099.8-1029.4 $\mathrm{cm}^{-1}$ indicative of the glycosidic character of the compound (Tang et al., 2003). The UV absorption maximum at $259.0 \mathrm{~nm}$ suggests the presence of $\alpha \beta \gamma \delta$-unsaturated nitrile group
(Dwuma-Bada et al., 1976; Takahashi et al., 1978; Seigler et al., 2005).

The HNMR spectrum confirms the presence of a glucosyl group in compound I as shown by the presence of a doublet signal at $4.571 \mathrm{ppm}\left(J=7.5 \mathrm{~Hz}, \mathrm{H}-1^{\prime}\right)$, a series of doublet-like signals centered at 3.336, 3.394, 3.287, 3.663, 3.881 and 3.336 (H-5', H-3', H$4^{\prime}, \mathrm{H}-6^{\prime} \mathrm{b}, \mathrm{H}-6^{\prime} \mathrm{a}, \mathrm{H}-2^{\prime}$ ) are strong signals for sugar protons. The large overlap of double doublets between 3.306 and $3.336 \mathrm{ppm}$ are indicative of glucose moiety. Two vinyl doublets appears at $6.289(\mathrm{H}-2)$ and $6.202(\mathrm{H}-$ 3) $\mathrm{ppm}$ and additional vinyl proton $(\alpha-\mathrm{H})$ at $5.512 \mathrm{ppm}$. Two other protons are on carbon bearing hydrogen: doublet at 4.913 and 4.371 $\{\mathrm{H}-6 \mathrm{ax}, 4 \mathrm{ax}\}$. The two geminally available protons appeared at 2.252 and $2.033 \mathrm{ppm}\{\mathrm{H}-$ 5eq and $\mathrm{H}-5 \mathrm{ax}\}$ respectively corresponding to the methylene protons. The absence of singlet at $\delta 3.70-3.90 \mathrm{ppm}$ is indicative of the relative absence of methoxyl group, similarly no peak was observed between $80.80-1.20$ ppm characteristics of Rhamnose sugar (Mabry et al., 1970; Manguro et al., 2005) and hence the absence of these molecules. The COSY spectrum showed the $\mathrm{H}-\mathrm{H}$ couplings; there is long range interactions observed between the protons, $\mathrm{H}-\mathrm{H}$ coupling shows some definitive 
information about the aglycone moiety of compound I. The unique coupling at $4.371(\mathrm{H}-$ $4 \mathrm{ax})$ is found coupled to up field protons at 2.033 and $2.252 \mathrm{ppm}$ ( $\{\mathrm{H}-5 \mathrm{ax}$ and $\mathrm{H}-5 \mathrm{eq}\}$ and equally to the three vinyl protons $(\mathrm{H}-\alpha, 2,3)$. The vinyl proton at $5.512 \mathrm{ppm}$ is coupled to the two other vinyl protons as well as to the peaks centered at 4.913 and $4.371 \mathrm{ppm} \mathrm{H-6ax,}$ 4ax ppm which is line with earlier reports by Jaki et al. (2003) and Seigler et al. (2005). The multiplicities and couplings observed on the aglycone are as follows: $\alpha-\mathrm{H}[5.512 \mathrm{ppm}], d$, $\mathrm{J}_{\alpha-6}=1.5 \mathrm{~Hz} ; 2-\mathrm{H}[6.287 \mathrm{ppm}], d d d, \mathrm{~J}_{3,2}=10.0$ $\mathrm{Hz}, \mathrm{J}_{2,4}=1.0 \mathrm{~Hz}, \mathrm{~J}_{2, \alpha}=1.0 \mathrm{~Hz}, 3-\mathrm{H}[6.202 \mathrm{ppm}]$, $d d, \mathrm{~J}_{2,3}=10.0 \mathrm{~Hz}, \mathrm{~J}_{3,4}=3.0 \mathrm{~Hz} ; 4 \mathrm{ax}-\mathrm{H}[4.371$ ppm], $m, \quad \mathrm{~J}=12.0 \quad \mathrm{~Hz} ; \quad 4 \mathrm{eq}-\mathrm{OH}[4.753$ $\operatorname{ppm}\{$ acetone $\}], d\{$ broad $\}, \mathrm{J}_{4-\mathrm{OH}, 4}=6.2 \mathrm{~Hz} ; 5 \mathrm{eq}-$ $\mathrm{H}[2.252 \mathrm{ppm}], d d d, \mathrm{~J}_{5,5}=13.0 \mathrm{~Hz}, \mathrm{~J}_{5,6}=8.5 \mathrm{~Hz}$, $\mathrm{J}_{5,4}=3.5 \mathrm{~Hz} ; 5 \mathrm{ax}-\mathrm{H}[2.033 \mathrm{ppm}], d d d, \mathrm{~J}_{5,5}=13.5$ $\mathrm{Hz}, \mathrm{J}_{5,6}=8.0 \mathrm{~Hz}, \mathrm{~J}_{5,4}=6.0 \mathrm{~Hz} ; 6 \mathrm{ax}[4.913 \mathrm{ppm}]$, $d d d_{6,5 \mathrm{ax}}=8.5 \mathrm{~Hz}, \mathrm{~J}_{6,5 \mathrm{eq}}=3.5 \mathrm{~Hz}, \mathrm{~J}_{6, \alpha}=1.5 \mathrm{~Hz}$. The couplings due to sugar protons showed multiplicities: $1^{\prime}-\mathrm{H}[4.571 \mathrm{ppm}], d,=7.5 \mathrm{~Hz} ; 2^{\prime}-$ $\mathrm{H}[3.336 \mathrm{ppm}], d d, \mathrm{~J}_{2^{\prime}, 3^{\prime}}=9.0 \mathrm{~Hz}, \mathrm{~J}_{2^{\prime}, 1^{\prime}}=6.5 ; 2^{\prime}-$ $\mathrm{OH}[4.956 \mathrm{ppm}\{$ acetone $\}], d d, \mathrm{~J}_{2^{\prime}-\mathrm{OH}, 2^{\prime}}=3.0 \mathrm{~Hz}$; $4^{\prime}-\mathrm{H}[3.287 \mathrm{ppm}], d d, \mathrm{~J}_{4^{\prime}, 3^{\prime}}=\mathrm{J}_{4^{\prime}, 5^{\prime}}=9.5 \mathrm{~Hz} ; 4^{\prime}-$ $\mathrm{OH}[4.939 \mathrm{ppm}\{$ acetone $\}], d, \mathrm{~J}_{4^{\prime}-\mathrm{OH}, 4^{\prime}}=3.0 \mathrm{~Hz}$; $3^{\prime}-\mathrm{H}[3.394 \mathrm{ppm}], d d, \mathrm{~J}_{3^{\prime}, 2^{\prime}}=\mathrm{J}_{3^{\prime}, 4^{\prime}}=8.5 \mathrm{~Hz} ; 3^{\prime}-$ $\mathrm{OH}\left[4.945\right.$ ppm\{acetone\}], $d, \mathrm{~J}_{3^{\prime}-\mathrm{OH}, 3^{\prime}}=2.5 \mathrm{~Hz}$; $5^{\prime}-\mathrm{H}[3.336 \mathrm{ppm}], d d d, \mathrm{~J}_{5^{\prime}, 4^{\prime}}=9.0 \mathrm{~Hz}, \mathrm{~J}_{5^{\prime}, 6 \mathrm{a}^{\prime}}=6.5$ $\mathrm{Hz}, \quad \mathrm{J}_{5^{\prime}, 6 \mathrm{~b}^{\prime}}=2.0 \mathrm{~Hz} ; \quad 6 \mathrm{a}^{\prime}-\mathrm{H}[3.663 \mathrm{ppm}], \quad d d$, $\mathrm{J}_{6 \mathrm{a}^{\prime}, 6 \mathrm{~b}^{\prime}}=12.0 \mathrm{~Hz}, \quad \mathrm{~J}_{6 \mathrm{a}^{\prime}, 5^{\prime}}=6.0 \mathrm{~Hz} ; \quad 6 \mathrm{~b}^{\prime}-\mathrm{H}[3.881$ $\mathrm{ppm}], d d, \mathrm{~J}_{6 \mathrm{~b}^{\prime}, 6 \mathrm{a}^{\prime}}=12.0 \mathrm{~Hz}, \mathrm{~J}_{6 \mathrm{~b}, 5^{\prime}}=2.0 \mathrm{~Hz}$ and $6^{\prime}-$ $\mathrm{OH}[4.520$ ppm\{acetone $\}], \mathrm{d}, \mathrm{J}_{6^{\prime}-\mathrm{OH}, 6^{\prime} \mathrm{b}}=11.5$ $\mathrm{Hz}, \mathrm{J}_{6^{\prime}-\mathrm{OH}, 6^{\prime} \mathrm{a}}=8.0 \mathrm{~Hz}$.

The ${ }^{13} \mathrm{CNMR}$ spectrum of the compound $\mathrm{I}$ in methanol exhibited fourteen carbon atoms approximately equal in height with some having characteristic chemical shifts equivalence. The presence of peak at 101.59 is typical of anomeric carbon of glucoside $\left(\mathrm{C}-1^{\prime}\right)$; other doublet peaks at 78.02 , $78.13,72.66,71.73$ and 63.11 ppm supported the fact that the compound contained $\beta$ glucopyranose moiety (Pauli, 1993; Seigler et al., 2005) and the presence of singlet peak at
$118.20 \mathrm{ppm}$ is assignable to the $\alpha \beta$ unsaturated nitrile carbon (Eudea et al., 1983; Seigler et al., 2005). Other signals at 36.14 ppm (a methane or methylene carbon, C-5) 65.42 and $74.55 \mathrm{ppm}$ (carbon bearing oxygen; C-4 and C-6 respectively) while the signal at 96.86, 127.85, 140.65 and $157.26 \mathrm{ppm}$ (aromatic or vinyl carbons; $\alpha-\mathrm{C}, \mathrm{C}-3, \mathrm{C}-2, \mathrm{C}-1$ respectively). The DEPT spectrum revealed that the peaks at $157.26 \mathrm{ppm}(\mathrm{C}-1)$ and 118.20 ppm $(\mathrm{CN})$ lack protons, those at $36.14 \mathrm{ppm}$ (C-5) and $63.11 \mathrm{ppm}$ (C-6') are methylene groups while the other nine carbons bear one hydrogen $\quad[\alpha-\mathrm{C}(96.86), \quad \mathrm{C}-2(140.65), \quad \mathrm{C}-$ $3(127.85), \quad \mathrm{C}-6(74.55), \quad \mathrm{C}-1^{\prime}(101.59), \quad \mathrm{C}-$ $2^{\prime}(72.66), \quad \mathrm{C}-3^{\prime}(78.02) \mathrm{C}-4^{\prime}(71.73)$ and $\mathrm{C}-$ $\left.6^{\prime}(78.13)\right]$.

The heteronuclear multiple bond quantum coherence (HMQC) spectra showed that there were interactions between the proton at $5.512 \mathrm{ppm}(\mathrm{H}-\alpha)$ and the vinyl carbon at $157.26 \mathrm{ppm}(\mathrm{C}-1)$, the carbon of the proton resonating at $4.913 \mathrm{ppm}(\mathrm{H}-6)$, the nitrile carbon and the sugar anomeric carbon, suggest that these groups are proximal in the structure. Because the methylene group protons at 2.252 and $2.025 \mathrm{ppm}$ (H-5eq, 5ax) are coupled both to the proton at $4.371 \mathrm{ppm}$ (H-4ax) and that at 4.913 ppm (H-6), a six membered ring is required (Seigler et al., 2005). The heteronuclear multiple bond coherence (HMBC) spectrum revealed strong long range-correlations between proton at $5.491 \mathrm{ppm}(\mathrm{H}-\alpha)$ and carbon at $127.85 \mathrm{ppm}$ (C-2) suggestive of cis-relationship, the proton equally interacted with the nitrile carbon at $118.20 \mathrm{ppm}$ suggesting that this proton and the nitrile group are attached to the same carbon atom. The signal $5.491(\mathrm{H}-\alpha)$ also interacted weakly with the oxygenbearing carbon at $74.55 \mathrm{ppm}$ (C-6) and the vinyl carbon at $157.26 \mathrm{ppm}(\mathrm{C}-1)$. There is a strong interaction of this proton $(\mathrm{H}-\alpha)$ with the anomeric carbon $\left(\mathrm{C}-1^{\prime}\right)$ at $101.59 \mathrm{ppm}$ which suggests that the site of attachment of the sugar is on the carbon at $74.55 \mathrm{ppm}$ (C-6) (Takahashi et al., 1978; Seigler et al., 2005). 
The NOESY experiment is designed to reveal the kind of protons that are closer in space showed that the proton at $4.373 \mathrm{ppm}$ (H-4) has an interaction with the vinyl proton at $6.202 \mathrm{ppm}(\mathrm{H}-3)$ while the proton at 4.913 ppm (H-6) interacted favourably with the anomeric proton at $4.571 \mathrm{ppm}\left(\mathrm{H}-1^{\prime}\right)$. Closer interactions between the anomeric proton $\left\{4.571 \mathrm{ppm}\left(\mathrm{H}-1^{\prime}\right)\right\}$ with the up field protons at $2.252 \mathrm{ppm}$ (H-5eq) and also $2.033 \mathrm{ppm}(\mathrm{H}-$ 5ax) were observed. The mass spectra showed base peak at $314.1243[\mathrm{M}+\mathrm{H}]^{+}$while the glucose fragmentation appeared at $\mathrm{M}^{+}$ 152.0715 when run with an internal standard \{[Glu]-Fibrinopeptide B . According to Takahashi et al. (1978), the mass spectra of the nitrogen containing compound mostly had an even numbered $\mathrm{M}+\mathrm{H}$ value in electron impact mode and therefore suggestive of nitrogenous compound. Consistently, the accurate mass measurement of compound I showed $\mathrm{M} / \mathrm{Z}$ peak at 313.1243 which is in a closer proximity to the isotopic theoretical value of $\mathrm{M} / \mathrm{Z}$ peak 313.1240. Therefore, taken collectively the spectral information suggested a planar conjugated system with two double bonds, a nitrile group, a glucose moiety and an oxygen-bearing carbon at $4.371 \mathrm{ppm}(\mathrm{H}-$ 4ax). Furthermore, the proton at $5.512 \mathrm{ppm}$ $(\mathrm{H}-\alpha)$ is in cis-relationship to one of the vinyl carbons. Based on the ${ }^{13} \mathrm{CNMR}$ and mass spectral data, the molecular formula requires six sites of unsaturation, hence a ring in both the sugar and the aglycone portion of the compound. Though, the structure of compound I was established earlier (Sosa et al., 1977; Takahashi et al., 1978; Nahrstedt and Wray, 1990; Seigler et al., 2005) as Menisdaurin; it is indeed, the first time the compound is run in acetone to confirm the $\mathrm{OH}$-configurations on the compound in relation to the earlier use of the DMSO by Takahashi et al. (1978). In line with the newer technologies in structure elucidation (HMBC, HMQC, NOESY), the spectral data of the isolated compound as shown by the conformational and structural configuration as $\mathrm{C}_{14} \mathrm{H}_{19} \mathrm{NO}_{7}$ conforms well with the compound's spectra data reported earlier by Seigler et al. (2005) as: $(4 S, 6 R)-(Z)-6-(\beta-\mathrm{D}-$ glucopyranosyloxy)-4-hydroxy-2-

cyclohexenyl- $\Delta^{1, \alpha}$-acetonitrile-a cyclohexenyl cyano methylene structure shown in the Figure 1 below.

Menisdaurin was considered noncyanogenic (Nahrsredt and Wray, 1990; Yamasaki, 1997) and was later noted to liberate small amount of cyanide by sandwich method of TLC (Seigler et al., 2005) and also under certain conditions there has been reports that cyanogenic glycosides with nitrile group alpha to the glycosidic linkage have been known to liberate HCN upon hydrolysis (Lechtenberg and Nahrstedt, 1999; Yamasaki, 1997). However, the mechanisms of cyanide liberation from Cyanogenic glycosides with nitrile group (example menisdaurin, ehretioside B) not adjacent to the glycosidic linkage still remain unknown (Yamasaki, 1997).

The susceptibility pattern shown on Table 1 revealed that wider diameters of inhibition zones (DIZ) of $16.67 \mathrm{~mm}$ were expressed against Gram-positive bacteria - $B$. subtilis (D2-8, D12-18) and Corynaebacterium spp. (D1). However, lower DIZ was found as $14.33 \mathrm{~mm}$ against Corynaebacterium spp. which was indeed higher than the value expressed by n-butanol portion at same dose (Usman et al., 2009b). The effects on Gram-negative bacteria were expressed by D2-8 with higher activity of $19.00 \mathrm{~mm}$ against $S$. dysenteriae while 14.33 $\mathrm{mm}$ was observed as the lowest DIZ expressed by D12-18 against $E$. coli.

The results on Table 2 below revealed high activity against $B$. subtilis at 0.625 $\mathrm{mg} /$ hole expressed by compound I; the least value of $14.33 \mathrm{~mm}$ was however exhibited by D2-8 against same bacteria.

The bacterial activities indices shown on Table 3a,b indicates high activity index of $65.81 \%$ and $70.43 \%$ when computed with Ciprofloxacin and Erythromycin against $B$. subtilis and the least value of $39.81 \%$ and $43.42 \%$ when computed similar antibiotics 
against Corynaebacterium spp. More so, the AI against Gram-negative bacteria had higher percentage of $93.89 \%$ when computed with Ciprofloxacin and Gentamicin against $S$. dysenteriae. However, compound I had AI of $66.89 \%$ and $127.36 \%$ when computed with Ciprofloxacin and Gentamicin against E. coli; suggesting compound I being a better agent compared to Gentamicin against this notorious bacteria. The BSI indicated high percentage value of $91.67 \%$ against $S$. dysenteriae while $79.17 \%$ was lowest against $E$. coli and $B$. subtilis. The percentage activity varied from $66.67-100 \%$ against both Gram-positive and Gram-negative bacteria. The SII showed D2-8 having high value of $15.09 \mathrm{~mm}$ while compound I followed with a value of 14.62 $\mathrm{mm}$, expressing the compound being very active (Usman et al., 2007), and the APBS was higher towards Gram-positive bacteria with $93.33 \%$. This trend explains the efficacy of fraction D2-8 and compound I. These susceptibility patterns were similar to those reported earlier (Parekh et al., 2006; Usman et al., 2007; Geidam et al., 2007).

Although cyanogenesis was earlier reported in Fabaceae (Caesalpinioideae), this is the first report on the isolation and characterization of cyanogenic glucoside (menisdaurin) from the species $B$. rufescens as well as the bioassay directed antibacterial effects against some bacterial strains in vitro. This study therefore showed that menisdaurin was highly susceptible to $B$. subtilis and $S$. dysenteriae.

\section{ACKNOWLEDGEMENTS}

Authors are grateful to Prof. S. Gibbons and his Research Team at the School of Pharmacy (SoP), University of London for the spectral studies; the Management of University of Maiduguri for the provision of Research grant and sponsorship for the short research visit to SoP. The technical assistance rendered by Mr. S. Gamache of the department of medical microbiology is well acknowledged.

\section{REFERENCES}

Aibinu IE, Ohaegbulam VC, Adenipekun EA, Ogunsola FT, Odugbemi TO, Mee BJ. 2003. Extended-spectrum $\beta$-Lactamase enzymes in clinical isolates of Enterobacter species from Lagos, Nigeria. J. Clin. Microb., 41(5): 21972200.

Aibinu I, Adenipekun E, Odugbemi T. 2004. Emergence of quinolone resistance amongst Escherichia coli strains isolated from clinical infections in some Lagos State Hospitals in Nigeria. Nig. J. Health Biomed. Sci., 3(2): 73-78.

Akah PA, Nnaeto O, Nworu CS, Ezike AC. 2007. Medicinal plants used in the traditional treatment of peptic ulcer diseases. A case study of Napoleona Vogelli Hook and Planch (Lecythidaceae). Res. J. Pharmacol., 1(3): 67-74.

Burkill HM. 1995. The Useful Plants of West Tropical Africa (Vol. II). Royal Botanic Gardens, Kew: London, UK.

Dwuma-Bada D, Watson WH, Gopalkrishna EM, Okater TU, Knapp JE, Slatkin DJ. 1976. Constituents of West African medicinal plants XVI. Griffonin and griffonilide, novel constituents of Griffonia simplicifolia. Lloydia, 39: 385390.

El-Mahmood, AM, Ameh, JM. 2007. In vitro antibacterial activity of Parkia biglobosa (Jacq.) root bark extract against some microorganisms associated with urinary tract infections. Afr. J. Biotech., 6(11): 1272-1275.

Eudea K, Yasutomi K, Mori I. 1983. Structure of a new cyanoglucoside from Ilex warburgii Loesn. Chem. lett., 149-150.

FAO-UNEP. 1983. Notes on Trees and Shrubs in Arid and Semi Arid Regions. EMASAR Phase II. FAO: Geneva, Rome.

Forbes BA, Sahm DF, Weissfeld AS, Trevino EA. 1990. Methods for testing antimicrobial effectiveness. In Bailey and Scott's Diagnostic Microbiology, Baron 
EJ, Peterson JR, Finegold SM (eds). Mosby Co. St. Louis: Missouri; 171-194.

Geidam YA, Usman H, Abubakar MB, Ibrahim B. 2007. Effects of aqueous leaf extracts of Psidium guajava on bacteria isolated from the navel of day-old chicks. Res. J. Microbiol., 2(12): 960-965.

GraphPad Software. 1998. GraphPad Software InStat guide to choosing and interpreting statistical tests, GraphPad Software, Inc., San Diego California USA Version 50.0.6000.16387. Available online: www.graphpad.com

Iwu MW, Dancan AR, Okon CO. 1999. New antimicrobial and its origin. In Perspective on New Crops and Uses, Janica J (ed). Alexandra Press VA; 457462.

Jaki B, Chadwick L, Seigler D, Pauli G. 2003. J-code Cracking in the fingerprint dereplication of small molecules. Proc. of SMASH, Verona, Italy, Sept. pp. 20-25.

Lechtenberg M, Nahrstedt A. 1999. Cyanogenic glycosides. In Naturally Occurring Glycosides. Ikan R, (ed). John Wiley: Chicester; 147-191.

Mabry TJ, Markham KR, Thomas MB. 1970. The Systematic Identification of Flavonoids. Sringer-Verlag Inc.: New York, USA.

Manguro LOA, Ugi I, Lemmmen P. 2005. Flavonol glycosides from the leaves of Embelia keniensis. J. Chin. Chem. Soc. 52: 201-208.

Nahrstedt A, Wray V. 1990. Structural revision of a putative cyanogenic glucoside from Ilex aquifolium. Phytochem. 29: 3934-3936.

Odunayo RA, Aibinu IE, Adenipekun T, Adelowotan T, Odugbemi T. 2007. In vitro antimicrobial activity of crude extracts from plants Bryophyllum pinnatum and Kalanchoe crenata. Afr. J. Trad. CAM., 4(3): 338-344.

Pauli GF. 1993. Cardenolides aus Adonis aleppica Boiss. -Isolierung und Strukturaufklärung, $\mathrm{PhD}$ thesis,
University of Düsseldorf, Germany, p.110.

Parekh J, Karathia N, Chanda S. 2006. Evaluation of antibacterial activity and phytochemical analysis of Bauhinia variegata L bark. Afr. J. Biomed. Res., 9: 53-56.

Robbers J, Speedie M, Tyler V. 1996. Pharmacognosy and Pharmaceutical Biology Technology. Williams and Wilkins: Baltimore.

Shahidi BGH. 2004. New approaches in screening for antibacterials in plants. Asian J. Plt. Sci., 3(1): 55-60.

Seigler DS, Pauli GF, Fröhlich R, Wegelius E, Nahrstedt A, Glander KE, Ebinger JE. 2005. Cyanogenic glycosides and menisdaurin from Guazama ulmifolia, Ostrya virigniana, Tiquilia plicata and Tiquilia canescens. Phytochem., 66: 1567-1580.

Sosa A, Winternitz F, Wylde R, Pavia AA. 1977. Structure of a cyanoglucoside of Lithospermum purpurea-caeruleum. Phytochem., 16: 707-709.

Takahashi K, Matsuzawa S, Takani M. 1978. The constituent of the vines of Menispermum dauricum DC. Chem. Pharm. Bull., 26: 1677-1681.

Tang Y-P, Liu X, Yu B. 2003. Two new flavone glycosides from Valeriana jatamansi. J. Nat. Prod., 5(4): 257-261.

Usman H, Musa YM, Ahmadu AA, Tijjani MA. 2007. Phytochemical and antimicrobial effects of Chrozophora senegalensis. Afr. J. Trad. CAM, 4(4): 488-494.

Usman H, Abdulrahman FI, Kaita HA, Khan IZ. 2009a. Comparative phytochemical and antimicrobial evaluation of stem bark extracts of Bauhinia rufescens Lam (Caesalpinioideae-Leguminosae) and Sclerocarya birrea (A. Rich.) Hochst (Anarcardiaceae). Med. \& Aromat. Plt. Sci. Biotech., 3(SI1): 110-116.

Usman H, Abdulrahman FI, Kaita HA, Khan IZ. 2009b. Antibacterial assays of the solvents partitioned portions of methanol 
stem bark extract of Bauhinia rufescens Lam [Leguminosae-Caesalpinioideae]. Pacif. J. Sci. Tech., 10(2): 857-867.

Usman H, Abdulrahman FI, Kaita HA, Khan IZ. 2009c. Phytochemical and in-vitro antibacterial effects of Bauhinia rufescens Lam stem bark extract. Afr. J. Biomed. Res., 12(3): 209-217.

Usman H, Abdulrahman FI, Kaita HA, Khan IZ. 2012. Phytochemical and antibacterial effects of the column fractions of $n$ butanol portion of the methanol stem bark extract of Bauhinia rufescens Lam. Proceedings of $35^{\text {th }}$ Intern. Conf. of the Chem. Soc. of Nig. held at Alvan Ikoku Federal College of Education, Owerri, $17^{\text {th }}-21^{\text {st }}$ September. Vol. II. pp. 163-170.

Vlietinck AJL, Vanhoof L, Totte J, Lasure A, Vanden-Berghe D, Rwangabo PC, Mvukiyumwami J. 1995. Screening of hundred Rwandese medicinal plants for antimicrobial and antiviral properties. $J$. Ethnopharmacol., 46: 31-47.

World Health Organization (WHO) 2001. Traditional medicine. Fact sheet number 134. Revised May, 2003. Available on http/www.who.int/media centre fact sheet/fs/134.

Williams R. 2000. Antimicrobial resistance a global threat. Essent. Drug Monitor., 2829:1.

Yamasaki K. 1997. Non-cyanogenic cyanoglucosides. Presented at symposium on Plant Glycosides at Kunming, China. August $19^{\mathrm{Th}} \cdot 1-6$. 